University of Nebraska - Lincoln

DigitalCommons@University of Nebraska - Lincoln

\title{
Remnant Colloform Pyrite at the Haile Gold Deposit, South Carolina: A Textural Key to Genesis
}

\author{
Nora Foley \\ U.S. Geological Survey, Mail Stop 954, National Center, Reston, Virginia 20192 \\ Robert A. Ayuso \\ U.S. Geological Survey, Mail Stop 954, National Center, Reston, Virginia 20192 \\ Robert R. Seal II \\ U.S. Geological Survey, 954 National Center, Reston, Virginia 20192, USA, rseal@usgs.gov
}

Follow this and additional works at: https://digitalcommons.unl.edu/usgsstaffpub

Part of the Earth Sciences Commons

Foley, Nora; Ayuso, Robert A.; and Seal II, Robert R., "Remnant Colloform Pyrite at the Haile Gold Deposit, South Carolina: A Textural Key to Genesis" (2001). USGS Staff -- Published Research. 340.

https://digitalcommons.unl.edu/usgsstaffpub/340

This Article is brought to you for free and open access by the US Geological Survey at DigitalCommons@University of Nebraska - Lincoln. It has been accepted for inclusion in USGS Staff -- Published Research by an authorized administrator of DigitalCommons@University of Nebraska - Lincoln. 


\title{
REMNANT COLLOFORM PYRITE AT THE HAILE GOLD DEPOSIT, SOUTH CAROLINA: A TEXTURAL KEY TO GENESIS
}

\author{
Nora Foley, ${ }^{\dagger}$ Robert A. Ayuso, and Robert Seal, II \\ U.S. Geological Survey, Mail Stop 954, National Center, Reston, Virginia 20192
}

\begin{abstract}
Auriferous iron sulfide-bearing deposits of the Carolina slate belt have distinctive mineralogical and textural features - traits that provide a basis to construct models of ore deposition. Our identification of paragenetically early types of pyrite, especially remnant colloform, crustiform, and layered growth textures of pyrite containing electrum and pyrrhotite, establishes unequivocally that gold mineralization was coeval with deposition of host rocks and not solely related to Paleozoic tectonic events. Ore horizons at the Haile deposit, South Carolina, contain many remnants of early pyrite: (1) fine-grained cubic pyrite disseminated along bedding; (2) finegrained spongy, rounded masses of pyrite that may envelop or drape over pyrite cubes; (3) fragments of botryoidally and crustiform layered pyrite, and (4) pyritic infilling of vesicles and pumice. Detailed mineral chemistry by petrography, microprobe, SEM, and EDS analysis of replaced pumice and colloform structures containing both arsenic compositional banding and electrum points to coeval deposition of gold and the volcanic host rocks and, thus, confirms a syngenetic origin for the gold deposits.

Early pyrite textures are present in other major deposits of the Carolina slate belt, such as Ridgeway and Barite Hill, and these provide strong evidence for models whereby the sulfide ores formed prior to tectonism. The role of Paleozoic metamorphism was to remobilize and concentrate gold and other minerals in structurally prepared sites. Recognizing the significance of paragenetically early pyrite and gold textures can play an important role in distinguishing sulfide ores that form in volcanic and sedimentary environments from those formed solely by metamorphic processes. Exploration strategies applied to the Carolina slate belt and correlative rocks in the eastern United States in the Avalonian basement will benefit from using syngenetic models for gold mineralization.
\end{abstract}

\section{Introduction}

The Carolina slate belt hosts numerous precious and base metal occurrences and, in South Carolina, several large and economically important pyrite-dominated gold deposits: Haile, Howie, Barite Hill, Ridgeway, and Brewer (Fig. 1). The deposits can be generalized as disseminated gold-pyritesericite mineralized systems hosted by intensely altered (propylitic, silicic, and argillic) rocks (Worthington and Kiff, 1970; Bell, 1982). All of these deposits were or are being mined as low-grade heap-leach operations (LaPoint, 1995). The focus of this work is on the Haile deposit (Fig. 2A) -an ore deposit that we think, based on isotopic considerations, formed in a transitional sublacustrine-subaerial hot springs environment with variable amounts of volcanic, volcaniclastic, and immature sedimentary (epiclastic) components (Ayuso et al., 1997; Foley et al., 2000). For this study, we examined the characteristics of the earliest phase of sulfide mineralization in detail and tried to decode the relationship of the earliest phase to gold mineralization. We present here textural, mineralogical, and chemical evidence establishing unequivocally that disseminated pyrite and gold mineralization was deposited contemporaneous with volcanic and volcaniclastic sediments at the Haile mine.

\section{Proposed models for Carolina slate belt gold deposits}

Geologists working on gold deposits of the Carolina slate belt have long grappled with the problem of seeing through the regional lower greenschist facies metamorphism that characterizes the host rocks. Intense folding and structural deformation that accompanied Late Proterozoic and Paleozoic

\footnotetext{
† Corresponding author: e-mail,nfoley@usgs.gov
}

orogenic events have also affected the Carolina slate belt. Despite enormous progress made in explaining the geologic evolution of the region (e.g., Feiss, 1982; Dennis, 1995, and references therein; Gillon et al., 1995; Maddry and Kilbey, 1995), many important questions remain regarding the origin of rocks associated with gold mineralization.

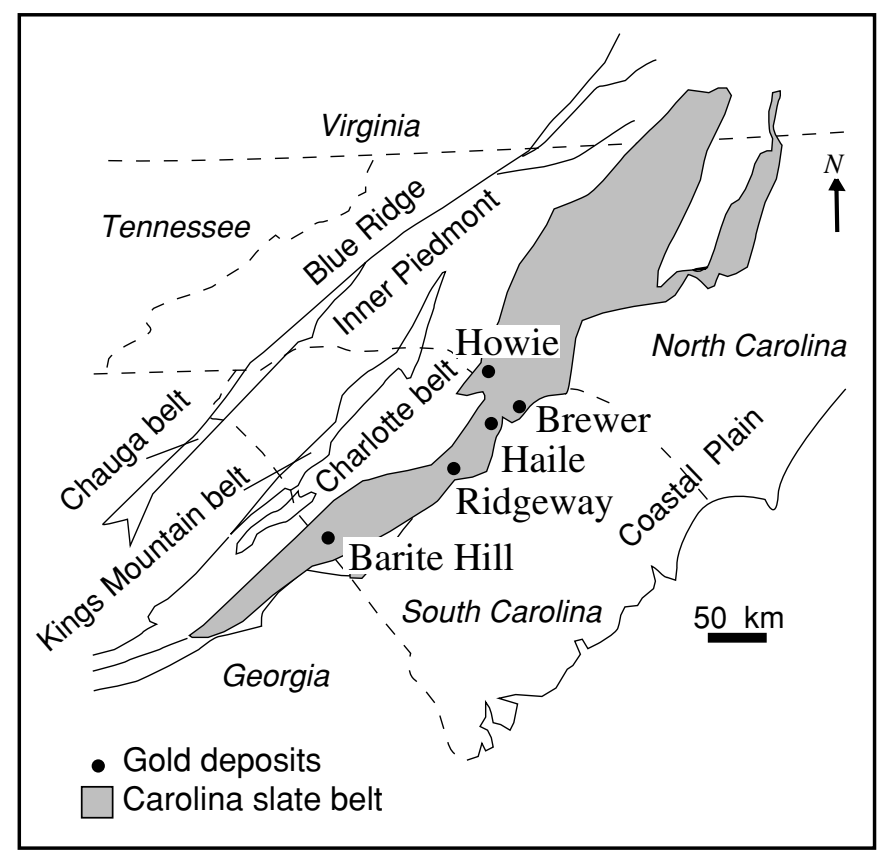

FIG. 1. Location of the Carolina slate belt relative to other terranes in the southeastern United States. Major gold deposits of the Carolina slate belt are located in South Carolina and North Carolina. 




FIG. 2. Generalized geologic map of the Haile deposit showing the locations of intensely mineralized areas, modified from Maddry and Speer (1992).

The significant issue in question concerning the origin of the Haile deposit is the timing of primary gold mineralization: both volcanic-associated and metamorphic models have been proposed. In 1970, Worthington and Kiff suggested a volcanogenic origin for some slate belt gold deposits including Haile. Felsic volcanic centers in the Carolina slate belt commonly have high alumina alteration patterns that correspond to those observed around modern hot spring systems (Spence, 1975). The Haile mine has been described as having exhalative gold and sulfides in chemical and epiclastic sediments and containing epigenetic gold in near-surface vent breccias (Speer and Maddry, 1993). However, high alumina alteration that overlies ore horizons at the Haile deposit is thought to be the result of saprolitic weathering of crystal tuff and unrelated to hydrothermal mineralization (Maddry and Speer, 1993).

In contrast, some studies have advocated a structurally controlled, metamorphic origin, perhaps associated with Paleozoic deformation and accretion of the Carolina terrane to North America during the Taconian orogeny. Syntectonic models of gold mineralization presented for the Haile deposit suggest that the mineralization is controlled by fold development (Hayward, 1992) or by development of shear zones (Tomkinson, 1988). In these models, siliceous fine-grained and thinbedded ore horizons are interpreted as syntectonic alteration products and designated silicified laminated phyllite.

Gillon et al. (1995) and Maddry and Kilbey (1995) established many of the key points of agreement on the genesis of gold deposits in the Carolina slate belt. Features that establish the timing of mineralization include the following: (1) chert beds present at the Haile and Ridgeway deposits originally formed as chemical sediments that were partially to completely converted to quartzite during metamorphism, (2) both deposits contain evidence that at least some mineralization predates the $\mathrm{S}_{2}$ cleavage, and (3) the presence of felsic volcanic rocks, volcaniclastics, and turbidites within the mineralized sequences at both deposits establishes a potential for synchronous volcanism and mineralization.

\section{General Geology}

Gold deposits of the slate belt occur near the transition between thick sequences of Late Precambrian to Cambrian (or about 600-520 Ma) orogenic metavolcanic rocks and an overlying sequence of volcaniclastic (and epiclastic) rocks (Worthington and Kiff, 1970). Recent studies have proposed that the change in rock type may be a result of the transition from an arc-related subaerial constructional phase to a rift-dominated, ring-fracture collapse of the arc below sea level (Feiss and Vance, 1995). Mineralized bodies that comprise the Haile deposit occur within metamorphosed crystal tuffs, volcaniclastic rocks, and siltstones of the Persimmon Fork Formation near a faulted contact with overlying epiclastic rocks of the Richtex Formation (Fig. 2B).

The Persimmon Fork Formation consists of calc-alkaline, intermediate and felsic volcanic and plutonic rocks, and metasedimentary (epiclastic) rocks at low metamorphic grade (Fig. 2B; Whitney et al., 1978; Secor et al., 1986; Dennis et al., 1993; Dennis, 1995; Harris and Glover, 1988; Kozuch et al., 1993). Crystal and lapilli tuffs and tuff breccias predominate but minor basaltic rocks are also found in the Persimmon Fork Formation. The Uwharrie and Persimmon Fork Formations are thought to be equivalent despite differences in $\mathrm{U}-\mathrm{Pb}$ 
zircon ages. The Uwharrie Formation in the Albemarle district in North Carolina yielded an older U-Pb zircon age of $586 \pm$ $10 \mathrm{Ma}$ (Harris and Glover, 1988). In the central-eastern Piedmont of South Carolina, U-Pb zircon ages for the Persimmon Fork Formation suggest a younger age, at about ca. $550 \mathrm{Ma}$ (Dennis, 1995, and references therein). Foley et al. (2000) used SIMS techniques to date zircons collected from volcanic rocks hosting the mineralization and occurring near the mines. Volcanic rocks analyzed by Ayuso et al. (1999) yielded data indicating an age of about $550 \pm 5 \mathrm{Ma}$.

The Richtex Formation, a clastic metasedimentary-metaigneous unit, overlies the Persimmon Fork Formation and consists of mudstones and turbiditic wackes with minor mafic rocks (Dennis, 1995). The Richtex Formation may be equivalent to the Tillery Formation of the Albermarle Group and to the mudstone-metabasalt sequence overlying the Lincolnton metadacite and, thus, have ages in the range 550 to 530 Ma (Dennis, 1995). Intercalated bimodal flows and tuffs are also found in the Richtex sequence (Feiss et al., 1993). In the vicinity of the mines, the Richtex Formation is intensely faulted, hydrothermally altered, and silicified near its contact with the Persimmon Fork Formation (Balinsky, 1994). The Richtex Formation is thought to be conformable and gradational with rocks near the Haile deposit, as well as those near the Ridgeway and Brewer mines (Balinsky, 1994). Turbiditic wackes of the Richtex Formation are thought to represent volcanic-derived debris accumulated in an intra-arc basin during rifting (Dennis, 1995).

Attempts to date molybdenite by Re-Os techniques yielded ages of $586.6 \pm 3.6$ and $553.8 \pm 9 \mathrm{Ma}$ (Stein et al., 1997). The relatively old Re-Os age compared to the zircon age of the host rock at about $554 \pm 2 \mathrm{Ma}$ is consistent with the occurrence of multiple generations of molybdenite at Haile, some of which are clearly fault related (Maddry and Kilbey, 1995). $\mathrm{Pb} / \mathrm{Pb}$ and $\mathrm{Ar}^{40} / \mathrm{Ar}^{39}$ isotope studies of closure histories of sulfide minerals and white micas for Haile, and other deposits in the region, have established open-system behavior related to metamorphism in all of the deposits (Ayuso et al., 1997).

Rocks of the Carolina slate belt have Avalonian affinities and thus are correlative with Late Proterozoic Avalonian rocks that occur in the Eastern United States, Atlantic Canada, and worldwide (Ayuso and Bevier, 1997; Ayuso et al., 1999). Avalonian rocks are especially well exposed in Newfoundland where they host a number of large hydrothermal alteration systems, including a sizeable gold mine at Hope Brook (Dubé and Dunning, 1997). The pyrite-gold-chalcopyrite ores at Hope Brook are high-sulfidation epithermal goldtype (Dubé and Dunning, 1997) ores of the Carolina slate belt Brewer gold deposit (Fig. 1). The age of mineralization at Hope Brook is bracketed between 578 and 574 Ma (Dubé et al. 1998; O’Brien et al, 1998). Other gold deposits of this type occurring worldwide include Pueblo Viejo, Dominican Republic (Russell and Kesler, 1991), which is hosted by Mesozoic volcanic rocks, and El Indio-Tambo, Chile (Arribas, 1995), which is contained within Tertiary-aged volcanic rocks.

\section{Methods of analysis}

Samples for this study were prepared by using standard thin section procedures for doubly polished thin sections and ore mounts. Quantitative wavelength dispersive analyses were determined by using a fully automated five-spectrometer JEOL JXA-8900R electron probe microanalyzer and ZAF data reduction. Point-mode analyses were determined using an accelerating voltage of $20 \mathrm{KeV}$ and a beam current of 3.0 $\times 10^{-8} \mathrm{~A}$. Trace element variations in pyrite were established by producing semiquantitative wavelength-dispersive elemental maps using an accelerating voltage of $20 \mathrm{KeV}$ and a beam current of $5.010^{-8} \mathrm{~A}$.

\section{Mineralogical Observations}

In the gold deposits of the Carolina slate belt, economic gold grades are found in silica-pyrite-rich phases of mineralization (e.g., Worthington and Kiff, 1970). Pyrite, the predominant sulfide, occurs as (1) fine-grained ( 10-100- $\mu$ m-wide) cubic crystals disseminated along bedding, (2) fine-grained spongy, rounded masses that may envelop or drape over pyrite cubes, (3) fragments of botryoidally and crustiform layered pyrite, and (4) pyritic infilling of vesicles and pumice. Pyrrhotite after pyrite is found at Haile, mainly as 2- to 6-mm grains that are elongated parallel to $\mathrm{S}_{2}$ and aligned within original $\mathrm{S}_{0}$ beds of disseminated pyrite (Maddry and Kilbey, 1995). Pyrrhotite also occurs as rare micrometer-sized blebs encased within pyrite and this pyrrhotite is most likely primary in origin.

The types of pyrite identified in this study (Fig. 3) and listed above are relatively undeformed; several varieties of deformed pyrite also occur at the Haile deposit: (1) metamorphosed or remobilized fine-grained pyrite in veins and offsets, (2) coarse aggregates and annealed pyrites (porphyroclasts), and (3) porphyroblastic pyrite. Ore horizons at the Haile deposit contain many examples of deformed and relatively undeformed types of pyrite. We focused this study on the relatively undeformed types of pyrites because they are the key to establishing the timing of gold mineralization.

\section{Gold in pyrite at Haile}

Within the more highly mineralized ore horizons at the Haile deposit, gold is found almost exclusively in fine-grained pyrite-bearing rocks (Speer and Maddry, 1993). High-grade gold concentrations occur in high silica, pyrite-rich rocks with accessory molybdenite, rutile, and potassium feldspar. We subdivide the sulfide mineral paragenesis at the Haile deposit into syngenetic (predeformation) and postdeformation stages based on mineral textures (Fig. 3). Predeformation stages consist of (I) an early Fe sulfide + electrum + pyrrhotite \pm molybdenite stage, and (II) a slightly later Fe sulfide, gold, chalcopyrite, arsenopyrite, and Au and Ag telluride stage. Postdeformation stages contain remobilized, recrystallized, and metamorphosed minerals of the earlier stages. This general paragenesis is consistent with observations by Speer and Maddry (1993) who described (1) thin, fine-grained undeformed sedimentary beds occurring in thick sequences of bedded metamudstones distal to the known orebodies; (2) fine-grained massive to semimassive sulfide which is often bedded and is typical of the pyrite-sericite schists in footwall rocks; (3) pyrite oriented along cleavage and shear planes in deformed rocks, often at a sharp angle to bedding; (4) medium- to coarse-grained pyrite intimately mixed with silica and generally lacking an oriented fabric; and (5) isolated cubes (2-25 mm) occurring rarely as porphryoclasts (larger 


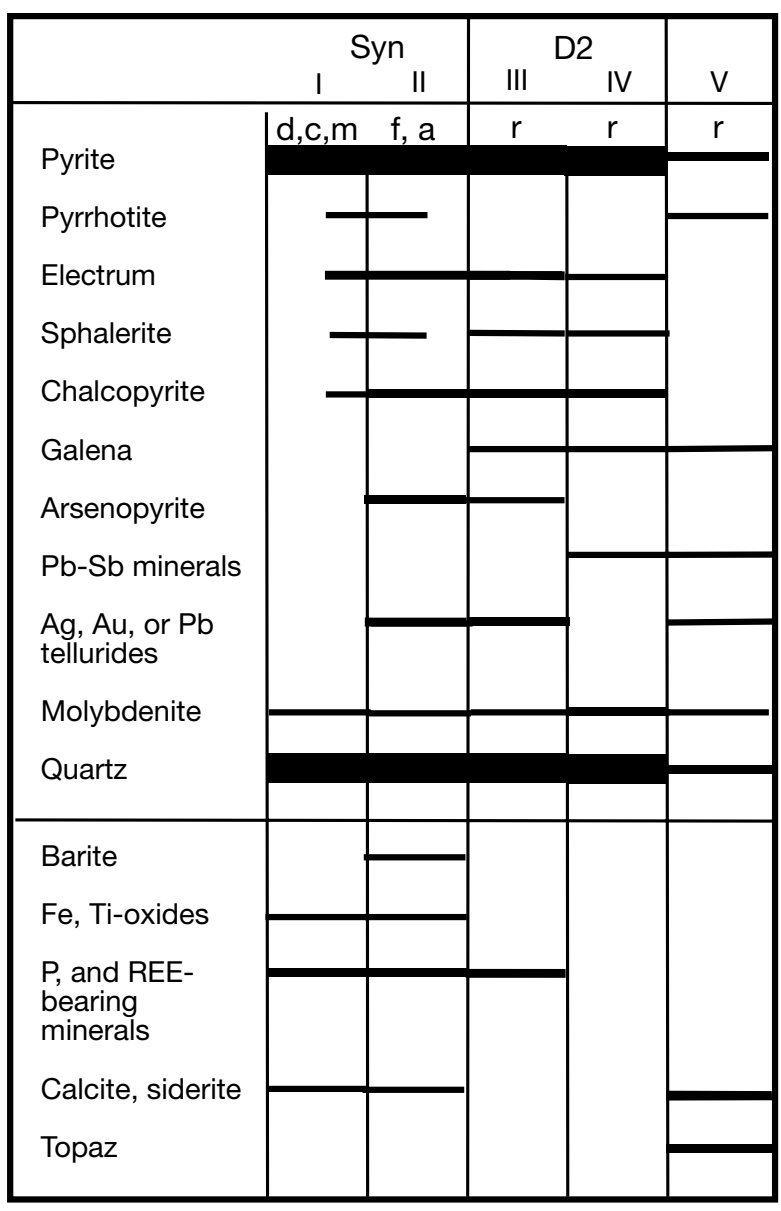

FIG. 3. Generalized paragenetic sequence describing minerals of the Haile deposit. Mineralized rock contains 1 to 15 percent Fe sulfide; iron sulfide minerals constitute $\sim 95$ percent of the total sulfides by volume. Abbreviations: $\mathrm{a}=$ aggregates, $\mathrm{c}=$ colloform growth textures, $\mathrm{d}=$ disseminated cubic, $\mathrm{f}=$ fine grained, $\mathrm{m}=$ massive, $\mathrm{r}=$ recrystallized; Syn = syngenetic, $\mathrm{D}_{2}$ $=$ major deformation event.

premetamorphic crystals) and more commonly as porphryblasts (metamorphosed and newly grown crystals). The third and fourth types of pyrite predominate in the ore zone and are associated with the highest gold contents.

Fine-grained immature volcaniclastic sedimentary rocks containing layers with distinctive volcanic textures dominantly host gold mineralization at the Haile deposit. Some mudstones examined in drill core show alternating finely laminated, graded beds of pyrite and sericite + quartz (Fig. 4A). Scanning electron microscopy (SEM) analysis shows that some of these pyrite layers contain fine-grained gold $(<5-\mu \mathrm{m}$ wide) mixed with sericite flakes. Deformation, probably Taconian, affected the rocks and many show a main fold $\left(\mathrm{F}_{2}\right)$ having good axial-plane cleavage (Fig 4B). Typically, smaller scale isoclinal folds $\left(\mathrm{F}_{1}\right)$ and an older foliation occur around the crest of this fold and both of them wrap around the large fold (the $F_{2}$ crest). Although there is evidence for late silicification along $S_{2}$ cleavage, the critical observation is that the main mass of silicified material was early because it was folded by both the large fold $\left(\mathrm{F}_{2}\right)$ and by the earlier isoclinal folds $\left(\mathrm{F}_{1}\right)$. We think that this means that the hydrothermal

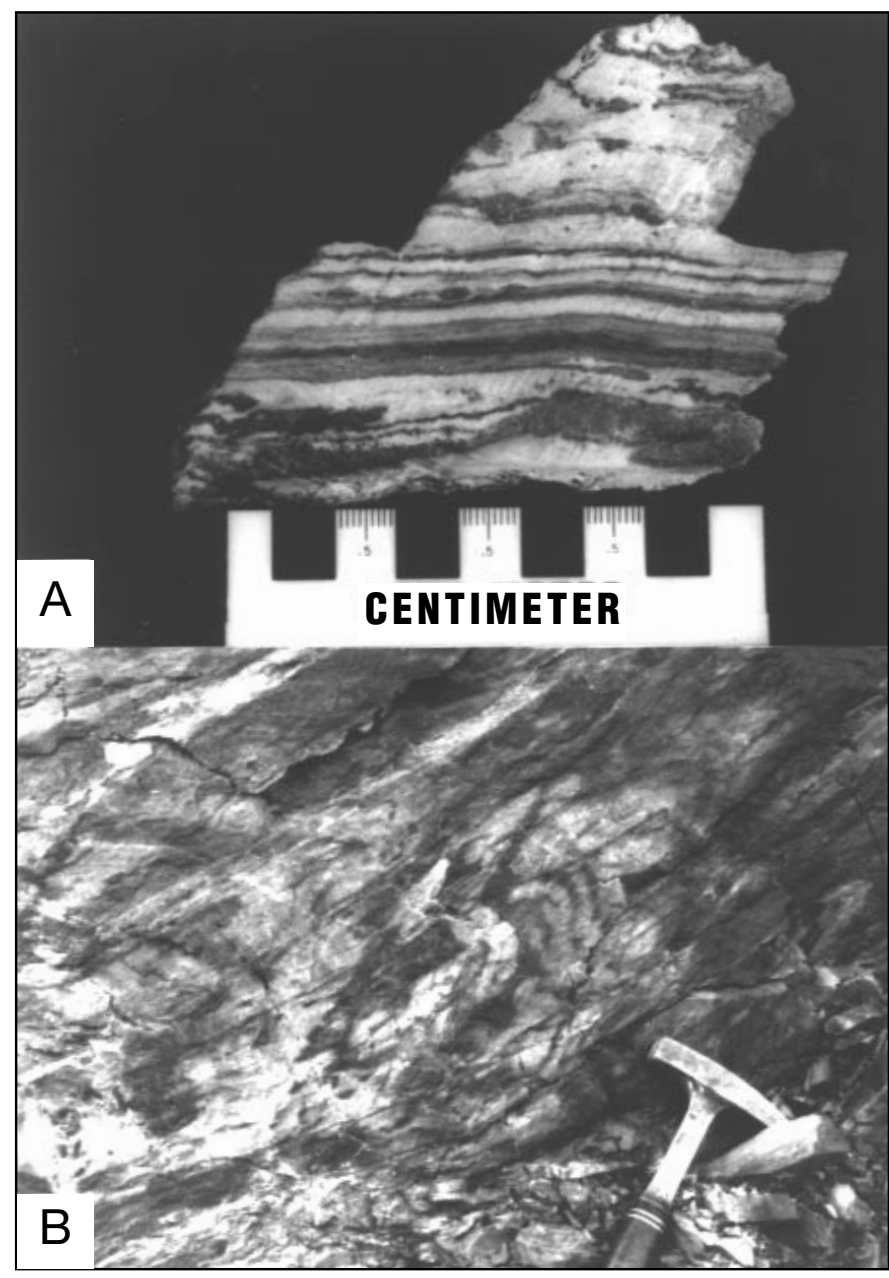

FIG. 4. Photographs showing structural evidence for timing of gold mineralization at the Haile deposit. A. Hand specimen of Persimmon Fork showing pyrite-bearing mudstones with isoclinally refolded synclines (lower right) and $\mathrm{F}_{1}$ folded by $\mathrm{F}_{2}$, a third stage of folding produced a cleavage weakly developed in the bottom left corner and late coarse pyrite overprints some parts of the original laminae. $\mathrm{B}$. Rock face showing main $\mathrm{F}_{2}$ fold crests.

alteration and silicification, which was almost certainly associated with the gold, was in fact, early. For example, samples (Fig. 4A) showing isoclinally refolded synclines $\left(\mathrm{F}_{1}\right.$ folded by $\mathrm{F}_{2}$ ) have the $\mathrm{F}_{2}$ fold crests that are wrapped by an older sericitic foliation. A third stage of folding is evidenced by weakly developed cleavage in some rocks (Fig. 4A) where a new, coarse generation of pyrite crystallized, overprinting some parts of the original laminae. Remnants of the pyrite formed during initial mineralization have what can be described as colloform or crustiform textures.

Crystal-rich tuffaceous rocks (Fig. 5A) at the Haile deposit typically contain phenocrysts of quartz and feldspar (now highly sericitized), lithic fragments, and mafic clots of chlorite and iron oxide. Textures which characterize vesicular, glassy, pyroclastic volcanic rocks, such as spherulitic (or lithophysae, which form as gas-filled bubbles in ash flows) cavities (Fig. $5 \mathrm{~B}$ ) and flattened pumice structures, are also found in finegrained, altered tuffaceous groundmass in rocks of the Haile deposit that contain pyrite-bearing horizons (Fig. 5C). In the sulfide-bearing horizons, lithophysae are now infilled with 


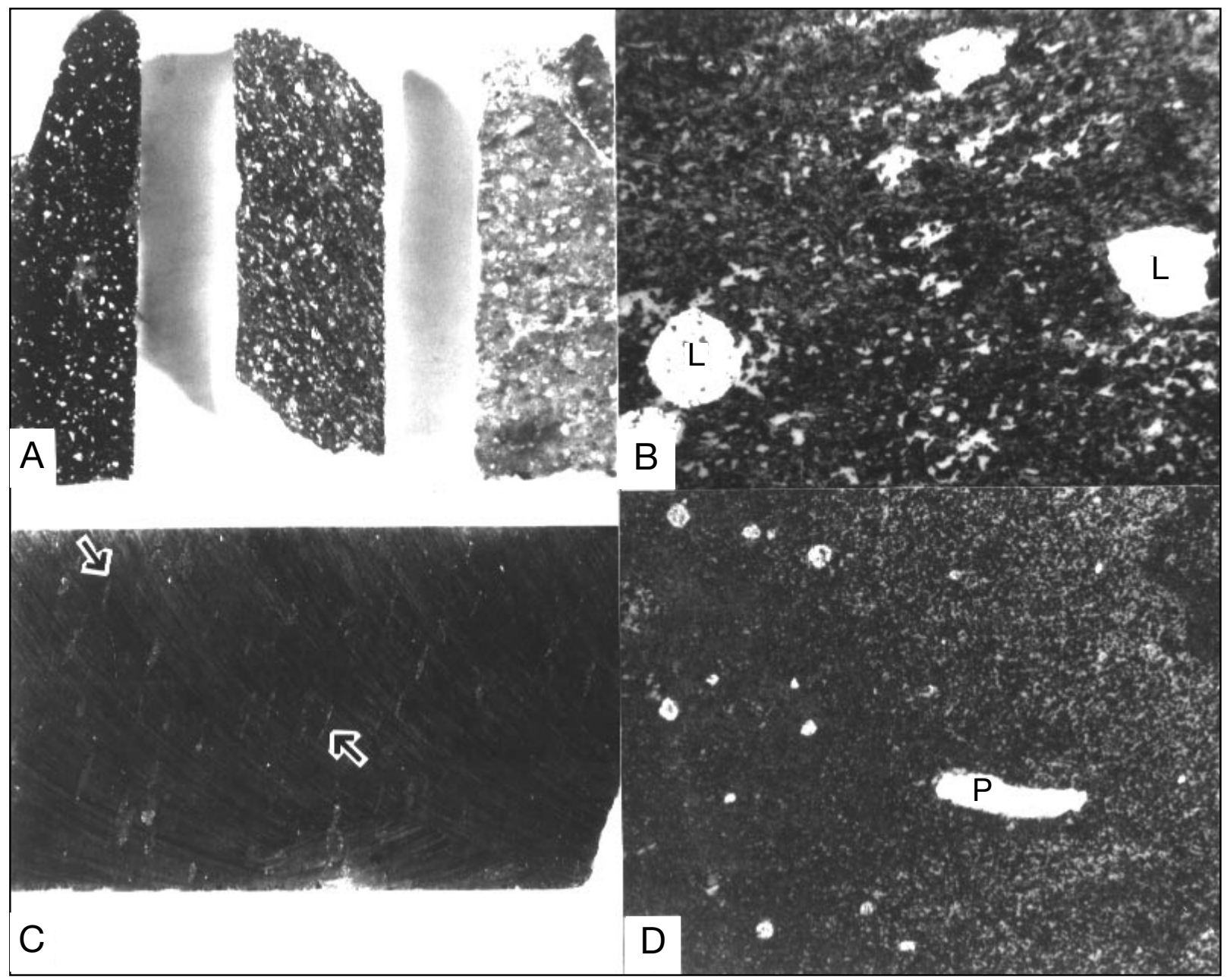

FIG. 5. Volcanic rocks textures at Haile. A. Drill core ( $5 \mathrm{~cm}$-wide) specimen of crystal-rich and lithic and pumice-bearing tuffs. B. Photomicrograph of phenocryst-rich and lithophysae (L)-bearing crystal tuffs (field of view $=1.0 \mathrm{~mm}$ wide). C. Drill core ( $5 \mathrm{~cm}$ wide) of pumice-bearing tuff; note that in this tuffaceous rock some of the pumice is replaced by pyrite (arrows). D. Photomicrograph of flattened pumice $(\mathrm{P})$ replaced by pyrite, quartz, and other minerals (field of view $=4.5 \mathrm{~mm}$ wide).

quartz and magnetite, while flattened pumice structures are replaced by pyrite and quartz (Fig. 5D). Flattened pumice also contains small blebs and thin layers of chalcopyrite and rare 1- to $5-\mu \mathrm{m}$-wide blebs of electrum within pyrite. The pyrite crystals are zoned for arsenic and arsenic contents range up to $3.5 \mathrm{wt}$ percent; other trace elements $(\mathrm{Au}, \mathrm{Ag}, \mathrm{Te})$ occur as discrete phases.

Electron microprobe maps of pyrite-filled pumice (Fig. 6) were prepared to document the distribution of a suite of trace elements including $\mathrm{Au}, \mathrm{Ag}, \mathrm{Fe}, \mathrm{S}, \mathrm{As}, \mathrm{Te}, \mathrm{Cu}, \mathrm{Pb}$, and $\mathrm{Zn}$. Wavelength dispersive maps of iron and arsenic clearly show wispy arsenic crystallization banding present in anhedral, rounded pyrite lining the pumices (Fig. 6A-D). Some euhedral pyrites within the pumices lack arsenic-rich layers. Areas of arsenic-bearing pyrite in pumice structures also contain micrometer-wide blebs of electrum that contain significant silver, as shown by semiquantitative microprobe analysis (Fig. 6E-F).

Paragenetically early pyrite in ore horizons at the Haile deposit commonly forms either as small inclusion-free euhedral cubes that have a high reflectivity or as anhedral shapes that are yellowish and less reflective than cubic pyrite (Fig. 7A) Anhedral pyrites have a porous nature that results in poor polished surfaces and a spongy appearance. Spongy masses of pyrite and the larger recrystallized pyrites and aggregates of the gold-rich, high silica, high pyrite zones contain abundant solid sulfide mineral inclusions-generally 5 - to $10-\mu \mathrm{m}$-wide blebs of chalcopyrite (most abundant), galena, sphalerite, argentite, electrum, and tellurides of gold, gold-silver, and copper. Many of the minerals occur within irregular layers and zones or at grain boundaries within the masses and aggregates of pyrite (Fig. 7B). The observed distribution of these inclusions is probably the result of metamorphic remobilization of the more malleable sulfides.

Although much of the pyrite at the Haile deposit was recrystallized and remobilized during metamorphism, fragments of spongy pyrite and original colloform textures are preserved in fine-grained bedded pyrite zones in quartz-sericite schists (Fig. 7C-E). Micaceous minerals may have taken up strain during metamorphism by curving and splaying around the silicified pyrite fragments and remnant colloform textures (Fig. 7C). Coarse (25- to 100- $\mu$ m-wide) late gold having a composition 

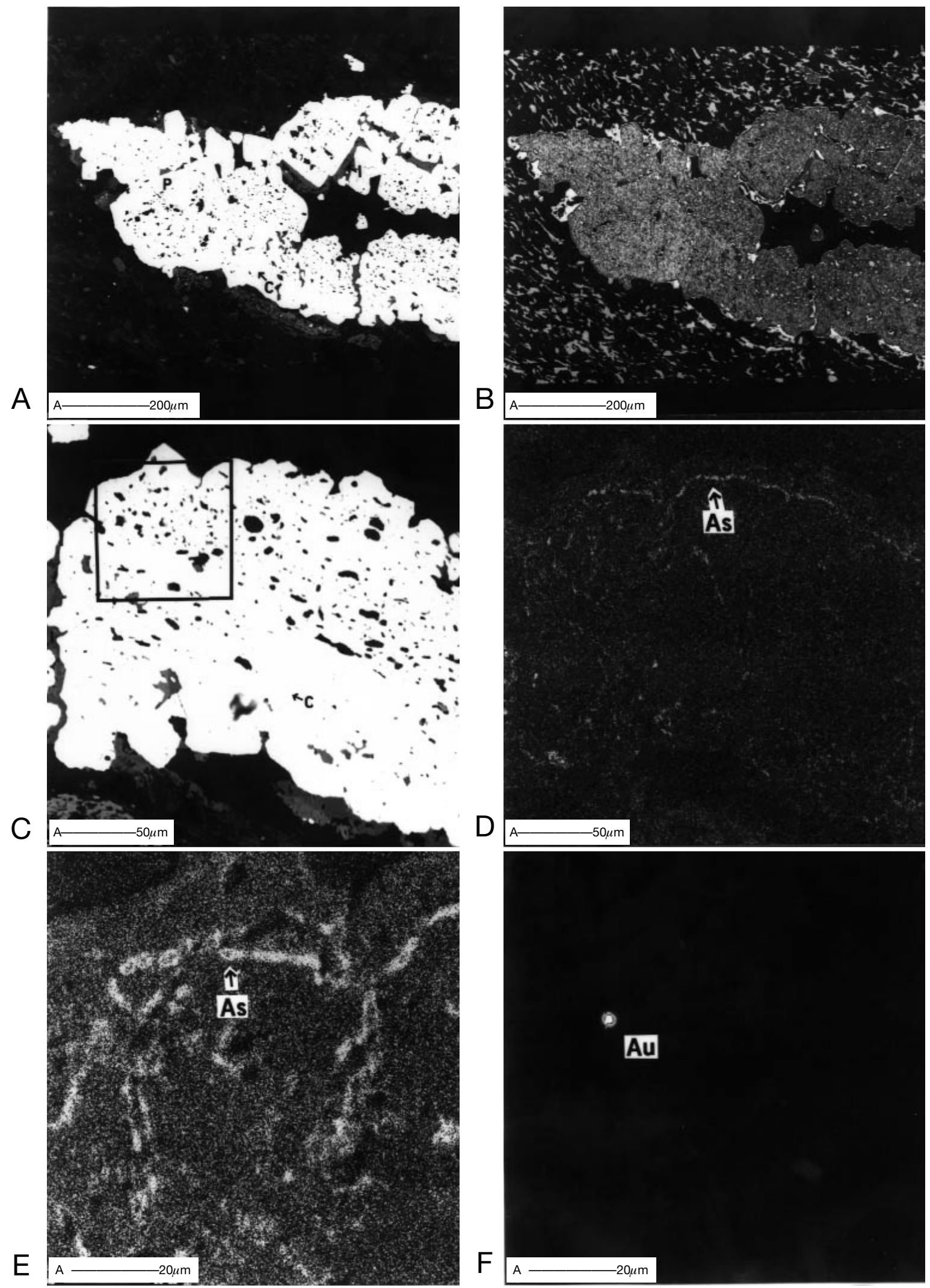

Fig. 6. Compositional maps of flattened pumice. A. Back-scattered electron image of pyrite (P, medium gray), chalcopyrite (C, white), and iron-oxide (I, dark gray) in pumice. B. Distribution of $\mathrm{Fe}$ in the sample (brighter areas are more $\mathrm{Fe}$ rich). C. Close-up view of lower right corner of (A). D. As (elemental) distributions present in pyrite (same view as C). E. Enlargement of inset box in (C), showing As distributions. F. Same view as (E), showing Au (as electrum) within the sample. 


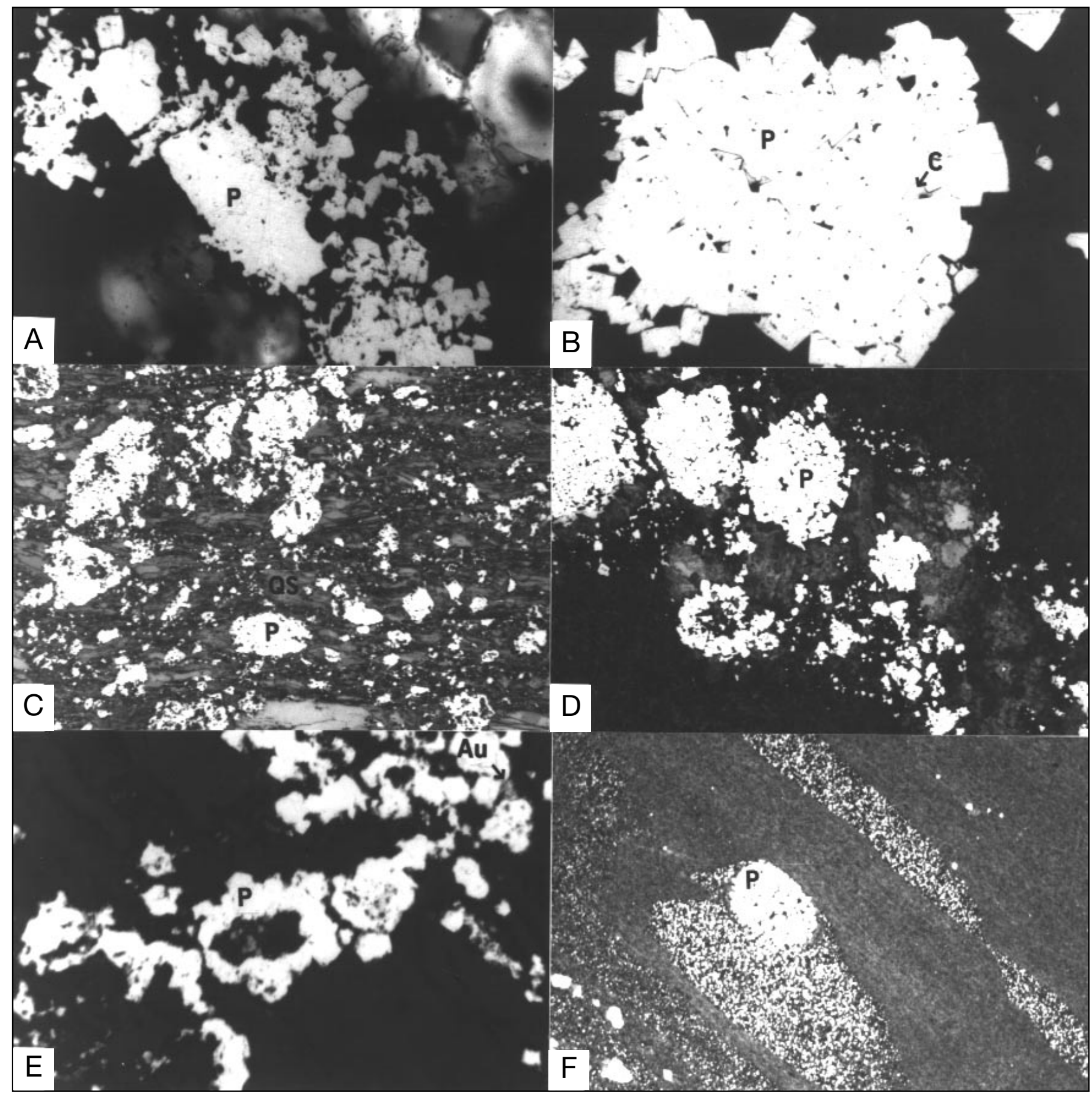

FIG. 7. Photomicrographs showing pyrite textures. A. Fine-grained spongy, rounded masses of pyrite that envelop and drape over euhedral pyrite $(\mathrm{P})$ debris. Arrow points to contact between two pyrite types (field of view $=4.5 \mathrm{~mm}$ wide). B. Aggregate of cubic pyrite $(\mathrm{P})$ with interstitial chalcopyrite $(\mathrm{C})$ (field of view $=45 \mathrm{~mm}$ wide). C. Fragments of botryoidal and crustiform layered pyrite $(\mathrm{P})$ in a quartz-sericite $(\mathrm{QS})$ matrix (field of view $=10 \mathrm{~mm}$ wide). D. Rounded masses of pyrite $(\mathrm{P})$ with variable amounts of disaggregation (field of view $=5 \mathrm{~mm}$ wide). E. Layered pyrites $(\mathrm{P})$ displaying spherical structures and distinct cores (field of view $=2.5 \mathrm{~mm}$ wide); late gold occurs between pyrite grains. F. Spherical pyrite structures in deformed pyrite-rich sediment (field of view $=1 \mathrm{~cm}$ wide).

of $\mathrm{Au}_{0.8-0.9} \mathrm{Ag}_{0.2-0.1}$ is locally found in quartz-sericite veins adjacent to fragments of the earliest pyrite generation (Fig. 7E).

Widely spaced micrometer-wide inclusions of electrum, pyrrhotite, and chalcopyrite occur in discontinuous layers within the botryoidal masses and layers of pyrite that make up the colloform textures. The layering in pyrite is compositional as well as textural. Figure 8A shows a back-scattered electron image of a well-preserved colloform pyrite having a delicate 
layered structure. Wavelength-dispersive maps of $\mathrm{Cu}, \mathrm{Ag}$, and $\mathrm{Au}$ confirm the presence of 5- to $20-\mu \mathrm{m}$-wide blebs of chalcopyrite and 1- to $7-\mu \mathrm{m}$-wide blebs of electrum within the layers of pyrite. Detailed elemental mapping of a small region in the pyrite (Fig. 8C-F) shows that the compositional layering apparent in the crustiform pyrite by back-scattered electron imaging is the result of alternating bands of low and high arsenic contents ranging from 0 to 3.1 wt percent (Fig. 8E). Minute blebs of gold (Fig. 8F), on the order of a few micrometers or less in diameter, are also present in the zoned pyrite, as are micrometer-wide pyrrhotite grains.

\section{Discussion}

We have described several field, textural, and mineralogical observations that demonstrate that gold mineralization was early at the Haile deposit and, moreover, that iron sulfidegold-silica deposition was contemporaneous with the formation of the volcanic and volcaniclastic rocks. Textures indicative of primary deposition of sulfides include growth fabrics, sedimentary textures, and colloidal textures (e.g., Ramdohr, 1980). Because sulfides exhibit varying tendencies to idiomorphic behavior, it is difficult to base genetic conclusions on growth fabrics. The discussions below focus on identifying and interpreting sedimentary and colloidal textures versus metamorphic textures in disseminated pyrite-sericite mineralized rocks.

Banded textures, such as those found in mudstones at Haile, are common in many ore environments and can form by a combination of hydrothermal and sedimentary processes (Ramdohr, 1980). The features described for Haile are consistent with syndepositional pyrite formation and contemporaneous sericitic alteration, as would be expected in the hotspring environment of Spence (1975). However, such textures often are difficult to distinguish from dynamically recrystallized textures that form during the structural folding and disruption of original bedding that accompanies regional metamorphism. Thus, banded or graded bedding of pyrite is not compelling proof of primary sedimentary deposition and we interpret this texture at Haile as only one line of evidence suggesting that mineralization was early.

Evidence for early gold mineralization at Haile was found by examining the replaced pumice and colloform pyrite textures interpreted to be present in the original mineralized volcanic host rocks. The presence of wispy remnants of original arsenic crystallization banding and micrometer-sized blebs of gold in anhedral, rounded pyrite lining pumices in the volcanic host rocks suggests mineralization contemporaneous with volcanism. The pumice structures appear to have been folded and stretched after pyrite replacement and some euhedral pyrites within the pumices lack arsenic-rich layers. Hence, recrystallization may have destroyed original arsenic compositional banding in those pyrites. The lack of pyrite veining in the matrix also supports early crystallization from mineralizing fluids that permeated the volcanic rocks.

Metacolloidal textures are a common and distinctive characteristic of massive and disseminated sulfide ores formed in submarine and subaerial exhalative deposits (e.g., Eldridge et al., 1983, figs. 10, 11; Poulsen and Hannington, 1996, plate 18). The textures of metacolloids-such as those found in ore horizons at Haile-commonly form when a metastable colloidal solution starts to crystallize. As water (or solvent) is lost, the residual material becomes microcrystalline and gradually increases in grain size. Co-precipitated substances (such as pyrrhotite, chalcopyrite, and electrum) may acquire exsolution-like textures due to hydrothermal reworking. Colloform, spheroidal, concentrically banded, crustiform, shell-like, botryoidal-reniform, and reticulate are some of the descriptive forms of metacolloids. At the Haile deposit, we recognize mostly colloform, crustiform, and shell-like textures of pyrites. A few of the larger euhedral pyrite crystals have distinctive cores that may have originally formed as spheroidal (or framboidal) pyrite overgrowths on mineral or microbial nuclei. Nearly every one of these pyrites shows some evidence for metamorphic recrystallization.

The layered sulfide masses at the Haile deposits are disseminated in a hydrothermally altered volcanic host containing significant amounts of quartz + sericite alteration. Remnants of crustiform pyrite containing sulfide and electrum inclusions most likely were protected from tectonic deformation by the sericite-rich nature of the host rocks. Metamorphic processes, such as dynamic recrystallization and annealing, generally result in disruption or recrystallization of colloidal textures and the loss of primary compositional layering, although metacolloidal textures are reported in weakly metamorphosed strata-bound sulfide deposits. Yui (1983) observed various stages of recrystallization of originally concentric colloform pyrite into pyrite cubes with chalcopyrite inclusions and embayments in ore samples from the Besshitype Motoyasu ore deposit (Yui, 1983, fig. 17a-h). Some of the recrystallized and metamorphosed pyrite at Haile may have formed by the process described for the Motoyasu deposit. The irregular pitted cores of colloform grains persist in many recrystallized pyrite cubes. Numerous pyrite porphyoblasts consist of rounded centers that contain small blebs and stringers of chalcopyrite and Ag and Ag telluride and sulfosalt minerals with overgrowths of cubic pyrite. Both euhedral and rounded pyrites typically have pitted cores that suggest a nucleus was once present. Because mineralizing bacteria are an important component in many hydrothermal environments, particularly submarine massive sulfide and hot springs, sulfide spheroids formed by bacterial action can also serve as a nucleus for colloidal structures. The small sulfide spheroids that form by bacterial processes are resistant to recrystallization and, in some cases, are the only relict textures in metamorphosed rocks and ore deposits (Ramdohr, 1980).

Pyrrhotite occurs extensively at the base and fringes of the ore deposits at Haile. At shallow depths where saprolitic weathering is present (above $80 \mathrm{~m}$ ), pyrrhotite only occurs as inclusions in pyrite (Maddry and Kilbey, 1995). We suggest two possible explanations for the occurrence of disseminated to semimassive pyrrhotite:

1. If the pyrrhotite is primary, then it most likely formed at a time or place when and where the hydrothermal fluids were at lower $f_{\mathrm{O}_{2}}$ and $f_{\mathrm{S}_{2}}$, or conversely, at higher temperature. As noted above, the presence of organic-rich sediments locally in the sequence could have buffered $f_{\mathrm{O}_{2}}$ at values low enough to allow formation of pyrrhotite. Minor to rare amounts of calcite of metamorphic origin now found in sphalerite- and 

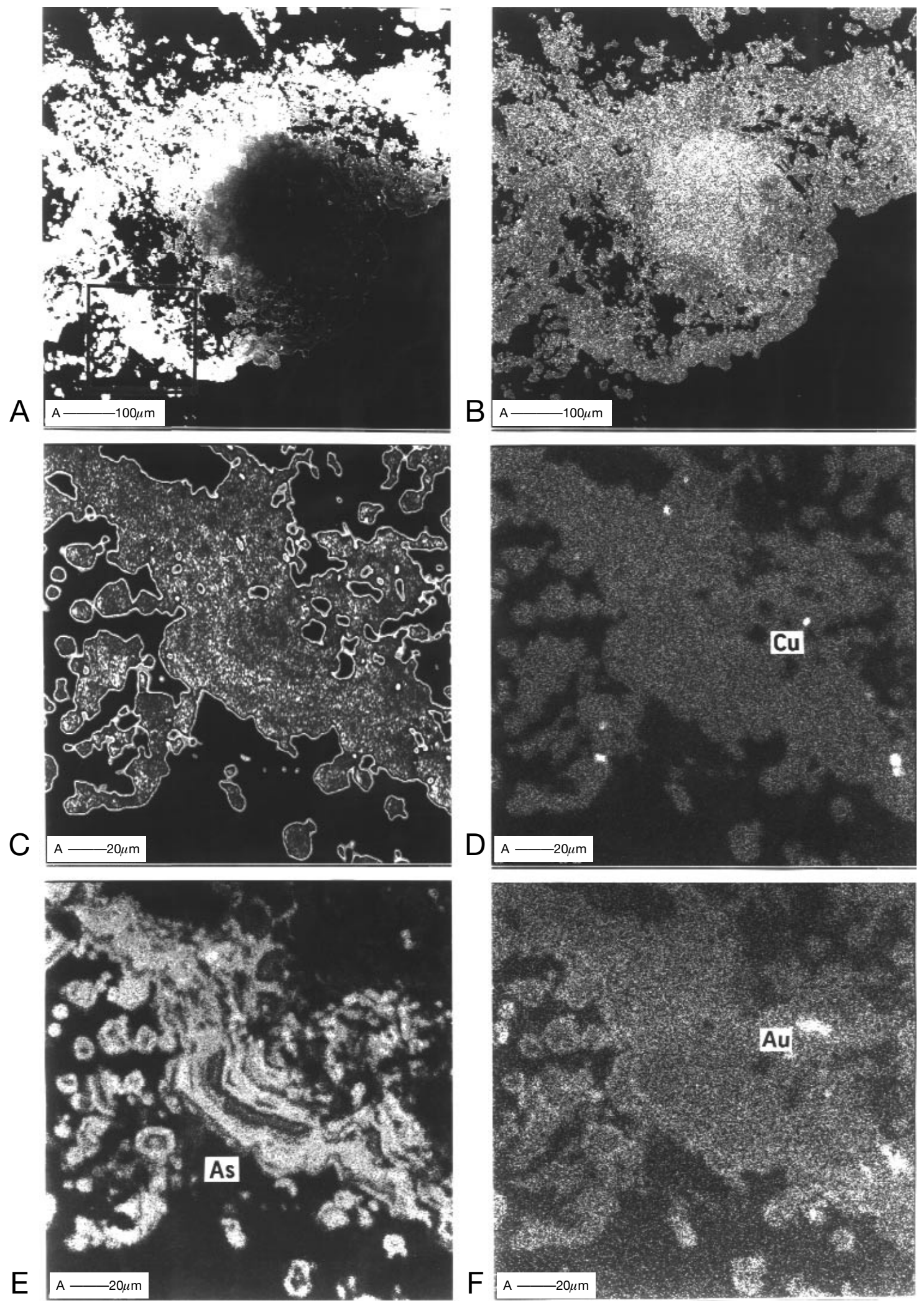

FIG. 8. Close-up of crustiform pyrite (see Fig. 7C), showing a relatively well preserved layered structure. A. Back-scattered electron image map of well-preserved colloform pyrite having a delicate layered structure. B. Elemental map of sulfur. Area shown in the inset box in (A) is enlarged in the next four photographs. C. Sulfur, shows subtle chemical zonation. D. Copper, confirms the presence of micrometer-sized blebs of chalcopyrite $(\mathrm{Cu})$. E. Arsenic (As), shows alternating bands of low and high arsenic contents that range from 0 to $3.3 \mathrm{wt}$ percent. F. Gold ( $\mathrm{Au})$, shows that electrum is also present in the lavers. 
galena-bearing veins suggest that carbon-rich layers were once present, although no other evidence is available. Temperatures of hydrothermal fluids in the basal part of the mineralized sequence were probably higher than temperatures in the upper part of the deposit because the volcanic rocks and semimassive sulfide layers would act as a thermal blanket and trap heat. This would favor formation of pyrrhotite at depth, whereas pyrrhotite blebs in pyrite high in the system are possibly metastable artifacts of the original mixture of iron monosulfide minerals.

2. Alternatively, pyrrhotite at the lower fringes of the orebodies may be entirely metamorphic in origin. It occurs together with calcite and porphyroblastic pyrite. At moderate to high metamorphic grades, pyrite typically begins to lose sulfur and is converted to pyrrhotite. Initial textural differences in pyrites may have caused fine-grained spongy pyrite to be converted to pyrrhotite more readily than the more refractory cubic types of pyrite that formed porphyoblasts.

Studies of sea-floor mineralization at mid-ocean ridges have established that fluids buffered at high $f_{\mathrm{O}_{2}}$ (typical of volcanic rock assemblages) precipitate pyritic assemblages, whereas those buffered at low $f_{\mathrm{O}_{2}}$ by reaction with sediment (organics) commonly precipitate assemblages dominated by pyrrhotite \pm arsenopyrite (Hannington et al., 1995). Based on our observations that primary magnetite was present in the volcanic and volcaniclastic host rocks, fluids depositing the crustiform pyrite at Haile were most likely buffered by pyrite + magnetite \pm pyrrhotite and did not react extensively with organic-rich sediments. The textures at Haile suggest that pyrite was initially deposited as a metastable mixture of iron monosulfides containing small amounts of gold, silver, arsenic, and copper. Crystallization and later reworking of the exhaled iron monosulfide colloidal mass led to the formation of delicate crustiform sulfides, primarily consisting of layered pyrite, pyrite with arsenic compositional zoning, and small stringers of chalcopyrite and blebs of chalcopyrite, electrum, and pyrrhotite.

\section{Comparison to other deposits}

The Haile deposit has petrographic and mineralogical features that support a stockwork disseminated model of pyritegold-sericite mineralization where a significant portion of the ore was deposited at or very near the surface. The gold-bearing sulfide ores at the Haile deposit, and those at the Ridgeway and Barite Hill deposits, are of the low-sulfidation type. These deposits are the shallow-water, submerged equivalents of intrusion-related high-sulfidation pyrite-chalcopyrite-enargite-gold ores such as those deposited a few kilometers away at the Brewer gold mine. Together, these deposits represent components of large solo intrusion-centered hydrothermal systems. Such systems typically consist of clusters of relatively small gold-rich submarine volcanic-associated massive sulfide deposits (e.g., such as the ores at Barite Hill, SC; Clark et al., 2000) and a number of larger, more extensive, disseminated gold-bearing pyrite bodies (such as at Haile and Ridgeway, SC), focused around the relatively rare and potentially giant high-sulfidation epithermal gold deposit (e.g., Brewer deposit).

The potential exists for additional discoveries of large solo intrusion-centered hydrothermal systems in the Eastern
United States, Canada, and worldwide. The occurrence of the Hope Brook deposit, Newfoundland, Canada, highlights the potential for preservation of high-sulfidation gold deposits in Late Proterozoic Avalonian rocks (Dubé et al., 1998; O’Brien et al., 1998). Recognizing that the gold ores of the Haile deposit represent a coeval component of mineralization suggests that similar deposits may be preserved throughout the Avalonian belt, especially in the vicinity of high-sulfidation epithermal deposits. Thus, successful exploration strategies for Haile- and Ridgeway-type components of these hydrothermal systems can be applied to the Carolina slate belt and correlative rocks in the Eastern United States in the Avalonian basement.

\section{Conclusions}

The arguments for a metamorphic origin for gold in many exhalative base metal deposits are based largely on observations at both the macroscopic and microscopic scales that most gold occurs late in the paragenesis - and is generally syntectonic (Poulsen and Hannington, 1996). Features formed by tectonic mechanisms typically dominate textural and mineralogical descriptions of deposits of this type and mineralogical and agrochemical evidence that provides compelling support for an early origin for gold-pyrite mineralization is often difficult to obtain (Poulsen and Hannington, 1996). Thus hypotheses invoking syntectonic origins generally cannot be discounted unequivocally. Early-formed pyrite textures such as the ones described here provide strong evidence for a model whereby the gold-bearing sulfide ores formed prior to tectonism. Subsequently, the role of metamorphism at Haile was to remobilize and concentrate gold and other minerals into structurally favorable sites. Comparable early-formed pyrite textures are found in ores of other gold deposits of the Carolina slate belt, including Barite Hill and Ridgeway (Foley et al., 2000). Recognizing their significance can play an important role in distinguishing sulfide ores that form in volcanic and sedimentary environments versus those formed solely by metamorphic processes.

A critical element in discerning the origin of gold at the Haile mine was identifying predeformation types of pyrite, especially remnant colloform, crustiform, and shell-like growth textures of pyrite containing electrum and pyrrhotite. These textures establish unequivocally that disseminated pyrite and gold mineralization were contemporaneous with the host volcanic and volcaniclastic sediments. The ore horizons contain many remnants of predeformation types of pyrite: (1) fine-grained cubic pyrite disseminated along bedding, (2) fine-grained spongy, rounded masses of pyrite that may envelop or drape over pyrite cubes, (3) fragments of botryoidal and crustiform layered pyrite, and (4) pyritic infilling of vesicles and pumice. Detailed examination of replaced pumice and colloform structures containing both arsenic compositional banding and electrum shows that gold deposition was syngenetic with the host volcaniclastic and epiclastic rocks.

Exploration strategies applied to the Carolina slate belt, (and to correlative rocks in the Eastern United States and Canada and slate belts worldwide; see for example, Ayuso et al., 1998; Dubé et al., 1998) should employ models where 
gold mineralization is considered contemporaneous with volcanic and volcaniclastic processes, and metamorphic remobilization and structural traps are involved in producing sites for gold accumulations. By all accounts, metamorphic processes have been important in creating and enhancing the structural setting of gold at deposits of the Carolina slate belt. Because unraveling the effects of metamorphic overprints on exhalative disseminated-submassive sulfide deposits is difficult, petrography and ore petrology studies of remnant textures, in concert with microanalytical techniques, will continue to be useful in discerning the original nature of gold-bearing sulfide mineralization. The deposits of the Carolina slate belt can be mined successfully, perhaps most effectively, based on structural models of mineralization; however, exploration strategies applied to the Carolina slate belt, and to correlative slate belts worldwide, will benefit from knowing the precise timing of gold mineralization relative to volcanic and volcaniclastic processes.

\section{Acknowledgments}

We thank the staff at the mines for their help in getting access to the deposits, for their invaluable assistance during sample collection, and for making maps and other pertinent documents available to us for this study. We gained fundamental insights into the genesis of these deposits from discussions with the mine geologists at each of the properties, in particular, Mark Zwaschka and John Sheetz at the Brewer mine (Brewer Gold Company); John Maddry and Tom Kilbey at the Haile mine (Cyprus AMAX Corp. and Piedmont Mining Co.); Tom Highsmith, Grant Eager, and Langdon Mitchell at the Ridgeway mine (Kennecott-Ridgeway Co); and Cam Allen and Kim Schroeder at the Howie mine (Cominco-American). Our ideas have also benefited from discussions with Ken Gillon (RMT, Inc) and Dennis LaPoint (Appalachian Resources).

August 12, 1999; February 9, 2001

\section{REFERENCES}

Arribas, A., Jr., 1995, Characteristics of high-sulfidation epithermal deposits and their relation to magmatic fluid: Mineralogical Association of Canada Short Course, v. 23, p. 419-454.

Ayuso, R.A., Foley, N.K., Seal, R.R., II, and Offield, T., 1997, Genesis of gold deposits in the Carolina slate belt, USA: Regional constraints from trace element, $\mathrm{Pb}$, and $\mathrm{Nd}$ isotopic variations and $\mathrm{Ar}-\mathrm{Ar}$ ages [abs]: Geological Society of America Abstracts with Programs, v. 29, p. A-60.

1998, Genesis of gold deposits in the Carolina slate belt, USA [abs]: Constraints from comparative mineralogy, trace elements, fluid evolution, and isotopic variations: Geology II Circum Atlantic Mineral Deposits Symposium, North Atlantic, Society of Mining, Metallurgy, and Exploration, Society of Mining Engineers Annual Meeting, Orlando, Florida, March 9-11 , Abstracts, p. 62 .

Balinsky, M., 1994, Field evidence for late Mesozoic and/or Cenozoic reactivation faulting along the Fall Line near Camden, South Carolina: Unpublished M.S. thesis, Columbia, University of South Carolina, 25 p.

Bell, H., III, 1982, Strata-bound sulfide deposits, wall-rock alteration, and associated tin-bearing minerals in the Carolina slate belt, South Carolina and Georgia: ECONOMIC GEOLOGY, v. 77, p. 294-311.

Dennis, A.J., 1995, The Carolina terrane in northwestern South Carolina: Relative timing of events and recent tectonic: Geological Association of Canada Special Paper 41, p. 173-190.

Dennis, A.J., Wright, J.E., Barker, C.A., Pray, J.R., and Secor, D.T., 1993, Late Precambrian-Early Cambrian orogeny in the South Carolina Piedmont [abs]: Geological Society of America Abstracts with Programs, v. 25, p. 484 .
Dubé, B., and Dunning, G., 1997, Potential for high sulfidation epithermal gold deposit in Canada: The example of the Hope Brook $\mathrm{Au}-\mathrm{Cu}$ deposit, Newfoundland: Gangue Newsletter, no. 157, p. 13-15.

Dubé, B., Dunning, G., and Lauzière, K., 1998, Geology of the Hope Brook mine, Newfoundland, Canada: A preserved Late Proterozoic high-sulfidation epithermal gold deposit and its implication for exploration: ECONOMIC GEOLOGY, v. 93, p. 405-436.

Eldridge, C.S., Barton, P.B., Jr., and Ohmoto, H., 1983, Mineral textures and their bearing on formation of the Kuroko orebodies: ECONOMIC GEOLOGY MONOGRAPH 5, p. 241-281.

Feiss, P.G., 1982, Geochemistry and tectonic setting of the volcanics of the Carolina slate belt: ECONOMIC GEOLOGY, v. 77, p. 273-293.

Feiss, P.G, and Vance, R.K., 1995, The Carolina terrane gold district: Rift-related volcanogenic gold deposits of the southern Appalachian Piedmont [abs]: Geological Society of America Abstracts with Programs, v. 27, p. A27.

Feiss, P.G., Vance, R.K., and Weslowski, D.J., 1993, Volcanic rock-hosted gold and base-metal mineralization associated with Neoproterozoic-Early Paleozoic back-arc extension in the Carolina terrane, southern Appalachian Piedmont: Geology, v. 21, p. 439-442.

Foley, N.K., Ayuso, R.A., Seal, R.R., II, Offield, T.W., Wooden, J.N., and Sinha, A.K., 2000, Mineralogical evidence for the age and origin of disseminated gold-iron-sulfide deposits of the Carolina slate belt, USA [abs.]: Geological Society of America Abstracts with Programs, v. 32, p. A-17.

Franklin, J.M., Lydon, J.W., and Sangster, D.F., 1981, Volcanic-associated massive sulfide deposits: Economic Geology 75Th AnNiversary Volume, p. $485-627$.

Gillon, K.A., Spence, W.H., Duckett, R.P., and Benson, C.J., 1995, Geology of the Ridgeway gold deposits, Ridgeway, South Carolina: Society of Economic Geologists Guidebook Series, v. 24, p. 53-94.

Hannington, M.D., Jonasson, I.R., Herzig, P.M., and Petersen, S., 1995 Physical and chemical processes of seafloor mineralization at mid-ocean ridges: Geophysical Monograph 91, p. 115-157.

Harris, C.W., and Glover, L., III, 1988, The regional extent of the ca. $600 \mathrm{Ma}$ Virgilina deformation: Implications for stratigraphic correlation in the Carolina terrane [abs]: Geological Society of America Abstracts with Programs, v. 100 , p. $200-217$

Hayward, N., 1992, Controls on syntectonic replacement mineralization in parasitic antiforms, Haile gold mine, Carolina slate belt: ECONOMIC GEOLOGY, v. 87, p. 91-112.

Kozuch, M., Mueller, P., Heatherington, A., Wooden, J., Koeppen, R., and Klein, T., 1993, Isotopic evidence in the Carolina slate and Charlotte belts (North Carolina) for reactivated Grenvillian and older sources [abs]: Geological Society of America Abstracts with Programs, v. 25, p. A-35.

LaPoint, D.J., 1995, Successful exploration techniques for Haile-Ridgeway type gold deposits in South Carolina: Society of Economic Geologists Guidebook Series, v. 24, p. 21-53.

Maddry, J.W., and Kilbey, T.R., 1995, Geology of the Haile gold mine: Society of Economic Geologists Guidebook Series, v. 24, p. 147-172.

Maddry, J.W., and Speer, W.E., 1993, Mineralite, deposits at the Haile gold mine, Lancaster County, South Carolina: South Carolina Geology, v. 36, p. $1-7$.

O’Brien, S.J., Dubé, B., O’Driscoll, C.F., and Mills, J., 1998, Geological setting of gold mineralization and related hydrothermal alteration in Late Neoproterozoic (post-640 Ma) Avalonian rocks of Newfoundland, with a review of coeval gold deposits elsewhere in the Appalachian Avalonian belt: Newfoundland Department of Mines and Energy Report 98-1, p. 93-124.

Poulsen, K.H., and Hannington, M.D., 1996, Volcanic-associated massive sulfide gold: Geological Survey of Canada, Geology of Canada, no. 8, p. 183-196.

Harris, C.W., and Glover, L., III, 1988, The ore minerals and their intergrowths, 2nd ed.: New York, Pergamon Press, 1205 p.

Russell, N., and Kesler, S., 1991, Geology of the maar-diatreme complex hosting precious metal mineralization at the Pueblo Viejo, Dominican Republic: Geological Society of America Special Paper 262, p. 203-216.

Secor, D.T., Jr., Snoke, A.W., Bramlett, K.W., Costello, O.P., Jr., and Kimbrell, O.P., 1986, Character of the Alleghanian in the southern Appalachians: Part I. Alleghanian deposits in the eastern Piedmont of South Carolina: Geological Society of America Bulletin, v. 97, p. 1319-1328.

Speer, W.E., and Maddry, J.W., 1993, Geology and recent discoveries at the Haile gold mine, Lancaster County, South Carolina: South Carolina Geology, v. 35, p. 9-26. 
Spence, W.H., 1975, A model for the origin of the pyrophyllite deposits in the Carolina slate belt [abs.]: Geological Society of America Abstracts with Programs, v. 7, p. 536.

Stein, H.J., Markey, R.J., Morgan, J.W., Hannah, J.L., Zak, K., and Sundblab, K., 1997, Re-Os dating of shear-hosted Au deposits using molybdenite: Mineral deposits: Research and exploration, where do they meet: Society for Geology Applied to Mineral Deposits Meeting, $4^{\text {th }}$ biennial, Turku, Finland, August 11-13, 1997, Proceedings, p. 313-317.

Tomkinson, M.J., 1988, Gold mineralization in phyllonites at the Haile mine, South Carolina: ECONOMIC Geology, v. 83, p. 1392-1400.
Whitney, J.A., Paris, T.A., Carpenter, R.H., and Hartley, M.E., III, 1978, Volcanic evolution of the southern slate belt of Georgia and South Carolina: A primitive oceanic island arc: Journal of Geology, v. 86, p. 173-192.

Worthington, J.E., and Kiff, I.T., 1970, A suggested volcanogenic origin for certain gold deposits in the slate belt of the Carolina Piedmont: ECONOMIC GEOLOGY, v. 65, p. 529-537.

Yui, S., 1983, Textures of some Japanese Besshi-type ores and their implications for Kuroko deposits: ECONOMIC GEOLOGY MONOGRAPH 5, p. 231-240. 